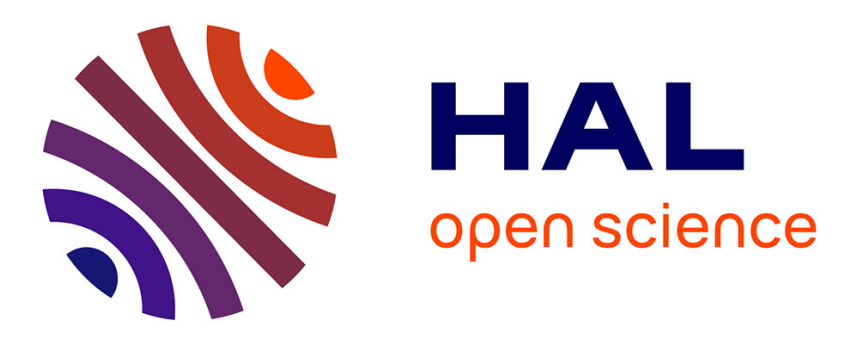

\title{
New phase transitions SC-SC2 and S Ad-SC2 in pure mesogens
}

\author{
Nguyen Huu Tinh, F. Hardouin, C. Destrade, H. Gasparoux
}

\section{To cite this version:}

Nguyen Huu Tinh, F. Hardouin, C. Destrade, H. Gasparoux. New phase transitions SC-SC2 and S Ad-SC2 in pure mesogens. Journal de Physique Lettres, 1982, 43 (21), pp.739-744. 10.1051/jphyslet:019820043021073900 . jpa-00232119

\section{HAL Id: jpa-00232119 https://hal.science/jpa-00232119}

Submitted on 1 Jan 1982

HAL is a multi-disciplinary open access archive for the deposit and dissemination of scientific research documents, whether they are published or not. The documents may come from teaching and research institutions in France or abroad, or from public or private research centers.
L'archive ouverte pluridisciplinaire HAL, est destinée au dépôt et à la diffusion de documents scientifiques de niveau recherche, publiés ou non, émanant des établissements d'enseignement et de recherche français ou étrangers, des laboratoires publics ou privés. 
Classification

Physics Abstracts

$61.30 \mathrm{E}-64.70 \mathrm{E}$

\title{
New phase transitions $S_{C^{-}}-S_{C_{2}}$ and $S_{A_{d}}-S_{C_{2}}$ in pure mesogens
}

\author{
Nguyen Huu Tinh, F. Hardouin, C. Destrade and H. Gasparoux \\ Centre de Recherche Paul Pascal, Université de Bordeaux I, 33405 Talence Cedex, France
}

(Reçu le 26 juillet 1982, accepté le 20 septembre 1982)

\begin{abstract}
Résumé. - Quatre homologues d'une série nouvelle 4-alcoxybenzylidène-4'-(4"-cyanobenzoyloxy) aniline sont présentés. Le dérivé decyloxy présente, pour la première fois, une transition $S_{C}-S_{C_{2}}$ dans une séquence $\mathrm{N} \mathrm{S}_{\mathrm{A}} \mathrm{S}_{\mathrm{C}} \mathrm{S}_{\mathrm{C}_{2}}$. L'identification de toutes ces phases a été effectuée conjointement par observation des textures au microscope et par l'étude des diagrammes de phase binaire. De plus, des mesures RX révèlent l'existence d'une nouvelle transition de phase $S_{A_{d}}-S_{C_{2}}$ dans le dérivé tridecyloxy.

Abstract. - Four homologues of the new series 4-alkoxybenzylidene-4'-(4"-cyanobenzoyloxy) aniline are presented. The decyloxy compound exhibits for the first time a $\mathrm{S}_{\mathrm{C}}-\mathrm{S}_{\mathrm{C}_{2}}$ transition with the $\mathrm{N} \mathrm{S}_{\mathrm{A}} \mathrm{S}_{\mathrm{C}} \mathrm{S}_{\mathrm{C}_{2}}$ sequence. Microscopic observations and binary diagram studies give this result. Furthermore a new $S_{A_{d}}-S_{C_{2}}$ sequence is revealed by $X$-ray measurements.
\end{abstract}

1. Introduction - Sigaud et al. [1] reported in 1978 the first example of a transition $S_{A}-S_{A}$ in a mixture between a polar compound 4-pentylphenyl $4^{\prime}-\left(4^{\prime \prime}\right.$-cyanobenzoyloxy) benzoate $\left(\mathrm{DB}_{5} \mathrm{CN}\right)$ and a non polar compound terephthal-bis butyl-aniline (TBBA). This transition $S_{A}-S_{A}$ was discovered by D.S.C. measurements and confirmed as $S_{A_{1}}-S_{A_{2}}\left(S_{A_{1}}\right.$ : monolayered smectic A phase, $S_{A}$, : bilayered one) by X-ray analysis [2]. Then, in 1980 there was revealed a transition $S_{A_{d}}-S_{A_{2}}\left(S_{A_{d}}\right.$ : partially bilayered smectic $A$ phase) in a pure compound [3] : 4-heptylphenyl $4^{\prime}-\left(4^{\prime \prime}\right.$-cyanobenzoyloxy) benzoate $\left(\mathrm{DB}_{7} \mathrm{CN}\right)$ and finally in a mixture, a sequence of transitions $S_{A_{d}}-S_{A_{1}}-S_{A_{2}}$ [4]. These results showed that there are probably three different smectic $A$ phases and suggested by analogy that it should be possible to obtain different transitions between smectic $C$ phases (it is evident to imagine that these phases are the tilted homologues of the various $\mathrm{S}_{\mathrm{A}}$ phases).

Now we present four homologues of the new series 4-alkoxybenzylidene-4'-(4"-cyanobenzoyloxy) aniline in which the decyloxy derivative exhibits a novel transition $S_{C^{-}} S_{C_{2}}$.

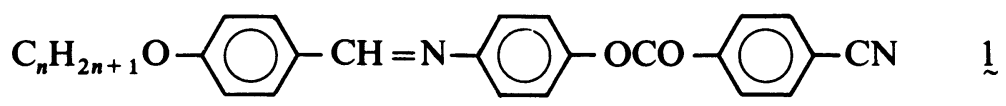

2. Results and discussion. - The substances were synthesized eitherby the condensation of the 4-alkoxybenzaldehydes and 4-(4'-cyanobenzoyloxy) aniline in ethanolic solution or by the esterification of 4-cyanobenzoyl chloride with the phenate of the 4-alkoxybenzylidene-4'-hydroxyaniline in benzene. They were purified by recrystallization from ethanol. Phase transitions were studied both by polarizing microscopy (equipped with a Mettler $\mathrm{FP}_{5}$ ) and differential scanning calorimetry (Dupont 990). 
The transition temperatures and types of mesophases are given in table $\mathrm{I}$.

Table I. - Transition temperatures $\left({ }^{\circ} \mathrm{C}\right)$ of compounds of the series $\underset{\sim}{1 .}$

\begin{tabular}{|l|ccccccccc|}
\hline$n$ & $\mathrm{~K}$ & & $\mathrm{~S}_{\mathbf{C}_{\mathbf{2}}}$ & $\mathrm{S}_{\mathbf{C}}$ & $\mathrm{S}_{\mathbf{A}_{\mathbf{d}}}$ & & $\mathrm{N}$ & & $\mathrm{I}$ \\
\hline 10 & $\cdot$ & 120 & $(106)$ & $(112)$ &. & 241 &. & 249 & $\cdot$ \\
11 & $\cdot$ & 112 & $(102)$ & - & $\cdot$ & 241 &. & 244 & $\cdot$ \\
12 & $\cdot$ & 117 & $(113)$ & - &. & 242 & - & & $\cdot$ \\
13 & $\cdot$ & 112 & $(110)$ & - & $\cdot$ & 234 & - & & $\cdot$ \\
\hline
\end{tabular}

$\mathrm{K}$; solid crystal; $\mathrm{S}_{\mathrm{A}}, \mathrm{S}_{\mathrm{C}}$ : smectic $\mathrm{A}, \mathrm{C}$;

$\mathbf{N}$ : nematic; $I$ : isotropic; . : the phase exists;

- : the phase is not observed; $($ ): monotropic transition.

The compound $n=10$ exhibits the tetramorphism : a nematic, a smectic $S_{A_{d}}$ and two smectic $C$ phases. On cooling the isotropic liquid of this compound one can observe the nematic phase with a schlieren texture (Fig. 1a). Below this nematic phase the smectic A phase with focal conics and homeotropic textures appears (Fig. 1b). On further cooling, the smectic $\mathrm{C}$ phase becomes visible through a schlieren texture in the previous homeotropic domains and through a broken fan shaped texture in the other ones (Fig. 1c). On cooling this $\mathrm{S}_{\mathrm{C}}$ phase another smectic phase makes its appearance as strongly birefringent droplets (Fig. 1d). On further cooling the droplets coalesce to give a schlieren texture typical of a $\mathrm{S}_{\mathrm{C}}$ phase (Fig. 1e). Let us point out that, with longer chains, the germination of this $S_{C_{2}}$ phase in the $S_{A}$ phase is in every respect similar (Fig. 2). The undecyloxy derivative exhibits the trimorphism $\mathrm{N} \mathrm{S}_{\mathrm{A}_{\mathrm{t}}} \mathrm{S}_{\mathrm{C}_{2}}$ and the nematic phase disappears in the two derivatives $n=12$ and 13 .

The smectic $S_{C_{2}}$ phases of these four compounds appear entirely miscible among themselves (Fig. 3) but not miscible with the high temperature $S_{C}$ phase of the decyloxy derivative. The bilayer $S_{C_{2}}$ nature (by analogy with bilayer $S_{A_{2}}$ ) is suggested by the phase diagram (contact method) between $n=13$ (or $n=10)$ and a standard compound 4-nonyloxy or decyloxyphenyl 4'-(4". nitrobenzoyloxy) benzoate $\left(\mathrm{DB}_{9} \mathrm{ONO}_{2}\right.$ or $\mathrm{DB}_{10} \mathrm{ONO}_{2}$ [5]) (Fig. 4). In addition three layering reflection orders are visible in the $X$-ray patterns of this phase with $d \simeq 51 \AA$ and the experimental tilt angle is large $\left(\theta>30^{\circ}\right)$ in agreement with the calculation of $\theta$ considering the expected bilayer $\mathrm{S}_{\mathrm{C}_{2}}$ arrangement with $d \simeq 2 l \cos \theta(l$ obtained from SASM stereomodel with the completely stretched conformation; $n=13, l \simeq 35 \AA$ ). The higher temperature $S_{\mathrm{A}}$ phase is not a bilayer but a partially bilayer $S_{A_{d}}$ phase with $d \simeq 53 \AA$ and with only one visible reflection order from the layers. Thus we think we have a new polymorphism $S_{A_{d}}-S_{C_{2}}$. Unfortunately we cannot confirm the $S_{C}-S_{C_{2}}$ sequence by $X$-ray experiments because in the $n=10$ compound both mesophases are too metastable and the crystallization first occurs in the supercooled region. Nevertheless we are able to confirm in the last compound that the $S_{A}$ phase is a partially bilayer $S_{A_{d}}(d / l \simeq 1.3)$ with an additional diffuse spot corresponding to the molecular length.

Acknowledgments - The authors are indebted to Dr. G. Sigaud and especially Dr. A. M. Levelut for the interest they manifest to this work and for discussions and helpful comments. 

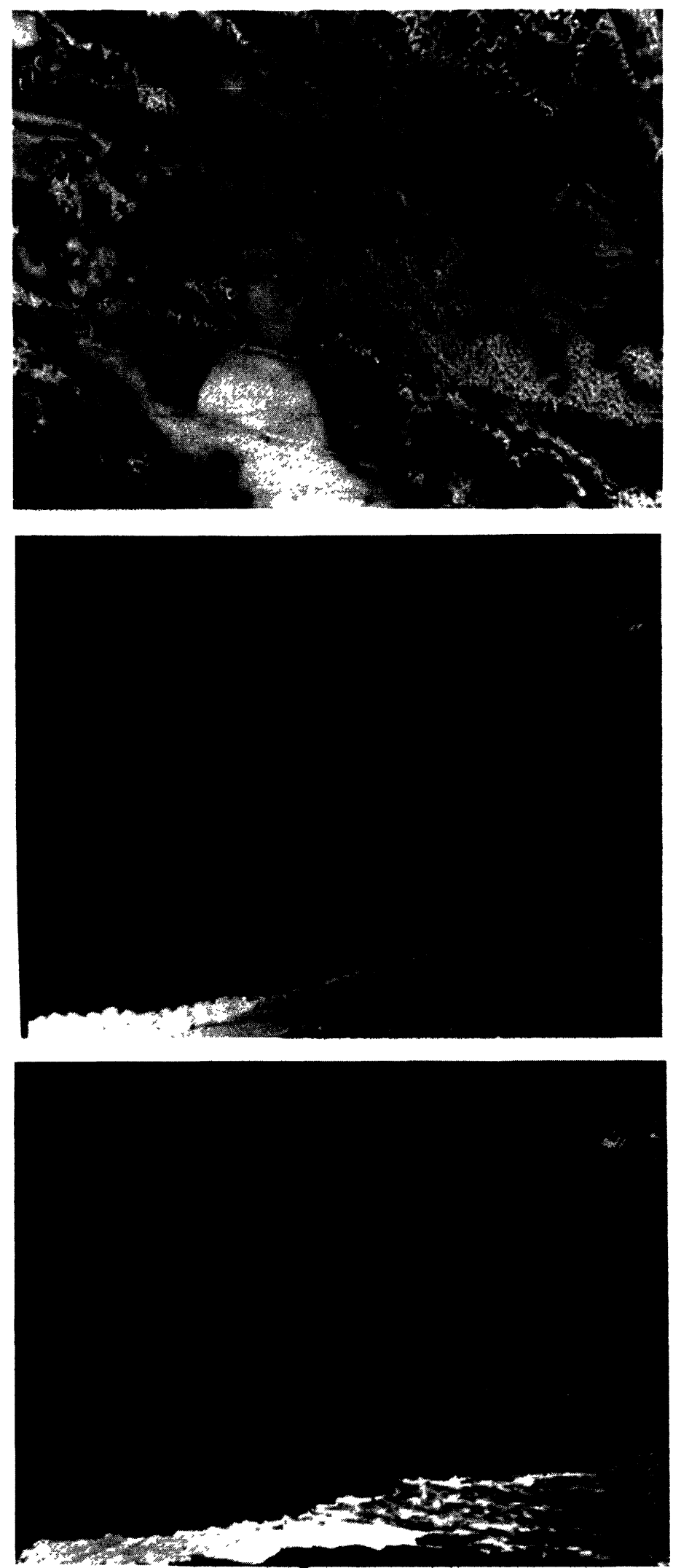

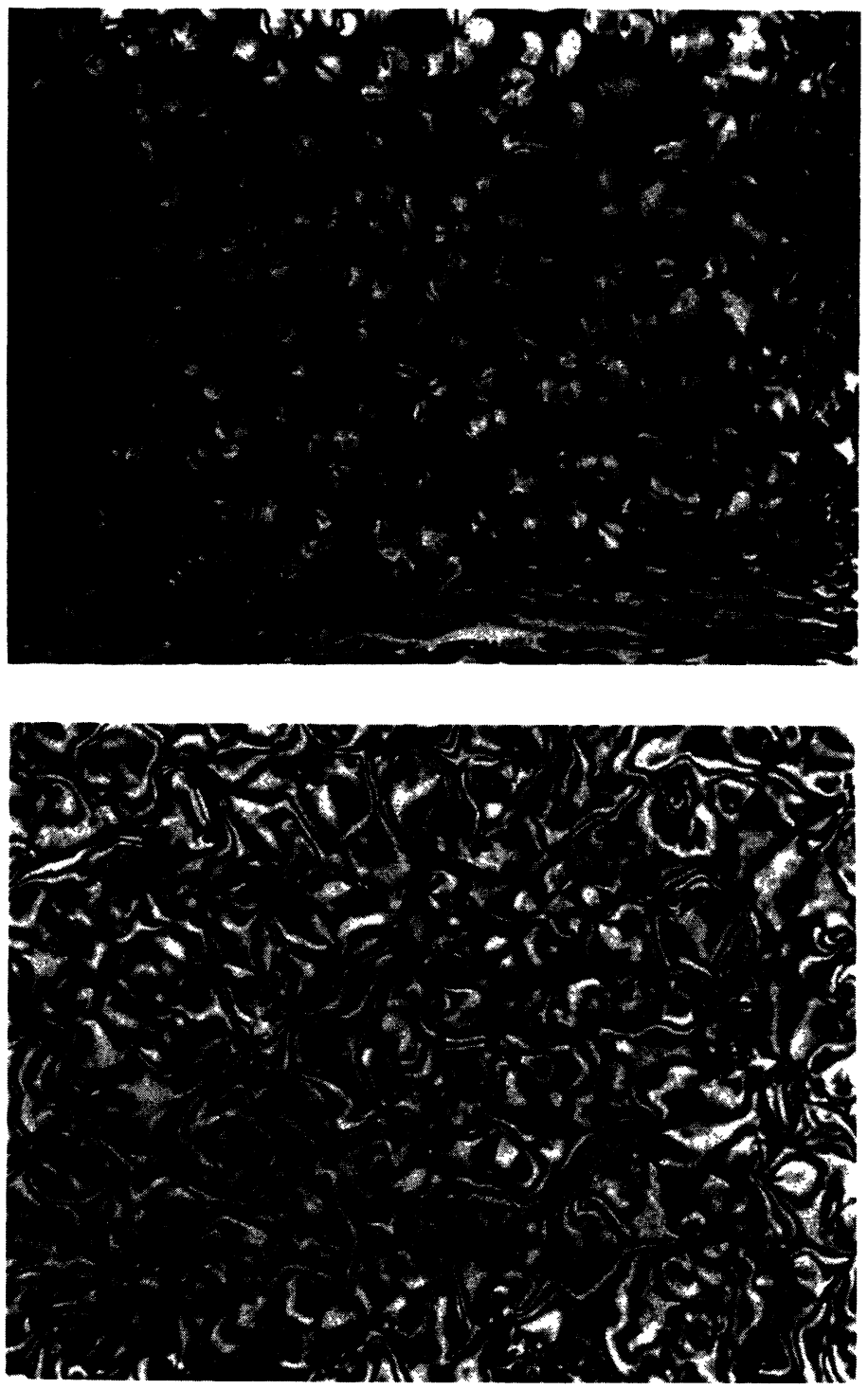

e)

Fig. 1. - Mesophases textures of the decyloxy derivative of $1: a)$ Nematic phase at $245^{\circ} \mathrm{C} ; b$ ) Smectic A phase $\left(\mathrm{S}_{\mathrm{A}_{\mathrm{d}}}\right)$ at $\left.150^{\circ} \mathrm{C} ; c\right)$ Smectic $\mathrm{C}$ phase at $\left.110{ }^{\circ} \mathrm{C} ; d\right)$ Appearance of $\mathrm{S}_{\mathrm{C}_{2}}$ phase in $\mathrm{S}_{\mathrm{C}}$ phase at $106^{\circ} \mathrm{C}$; e) $\mathrm{S}_{\mathrm{C}_{2}}$ phase at $104^{\circ} \mathrm{C}$. 


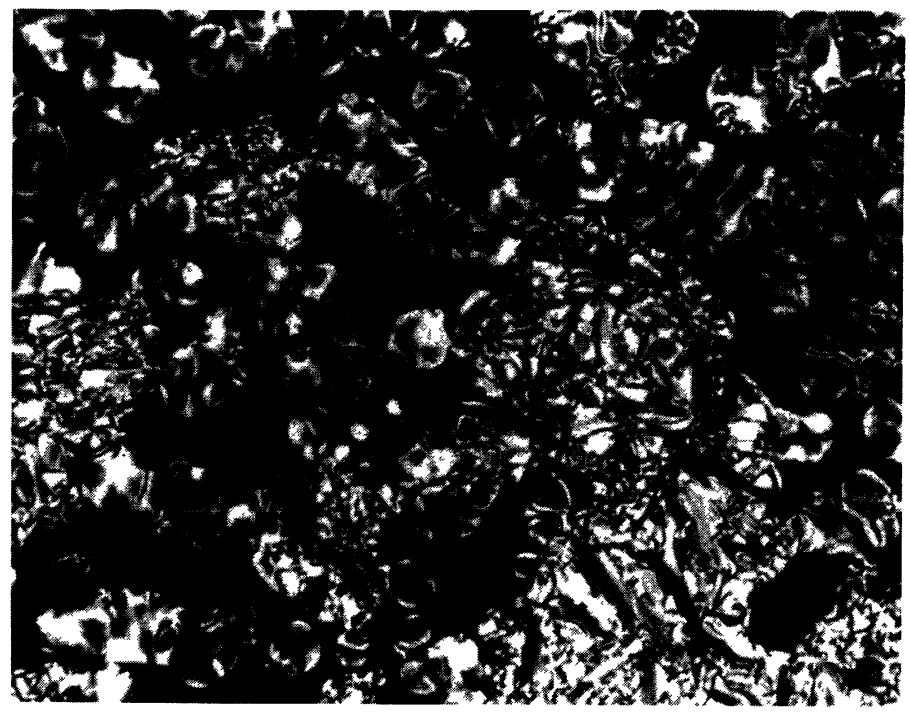

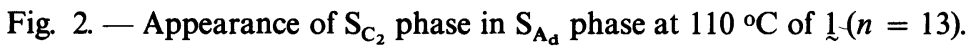

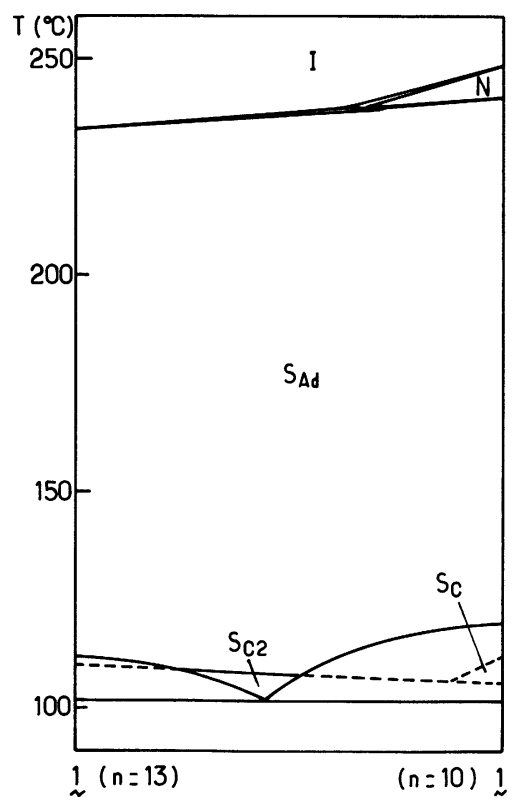

Fig. 3. - Phase diagram of mixtures of the compounds $\underset{\sim}{1,} n=13$ (on the left) and $\underset{\sim}{1,} n=10$ (on the right). 


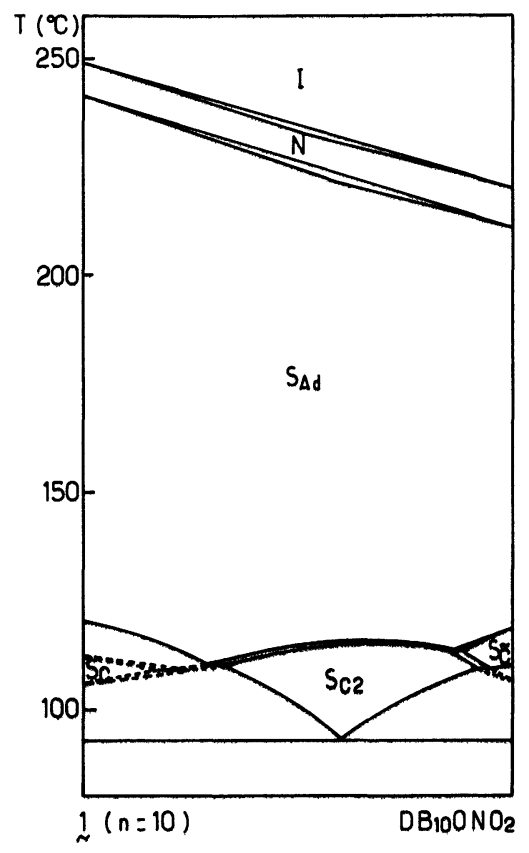

Fig. 4. - Phase diagram of mixtures of the compounds $\underset{\sim}{1, n}=10$ (on the left) and $\mathrm{DB}_{10} \mathrm{ONO}_{2}$ (on the right).

\section{References}

[1] Sigaud, G., Hardouin, F., Achard, M. F., Gasparoux, H., J. Physique Colloq. 40 (1979) C3-356.

[2] Hardouin, F., Levelut, A. M., Benattar, J. J., Sigaud, G., Solid State Commun. 33 (1980) 337.

[3] Hardouin, F., Levelut, A. M., Sigaud, G., J. Physique 42 (1981) 71.

[4] Levelut, A. M., Torento, R. J., Hardouin, J., Achard, M. F., Sigaud, G., Phys. Rev. A 24 (1981) 2180.

[5] Nguyen huu tinh, Hardouin, F., Destrade, C., J. Physique 43 (1982) 1127. 